\title{
ПСИХИЧЕСКОЕ ЗДОРОВЬЕ ЛГБ ПОДРОСТКОВОГО И ЮНОШЕСКОГО ВОЗРАСТА КАК ВЫЗОВ РОССИЙСКИМ ПСИХОЛОГАМ
}

\author{
Т.Н. ЛАПШИНА ${ }^{\mathrm{a}}$, А.С. КОЧЕТКОВА
}

${ }^{a}$ ГБОУ ВО МО «Академия сочиального управления», 129344, Россия, Москва, ул. Енисейская, д. 3, к. 5

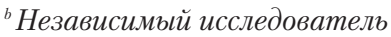

\begin{abstract}
Резюме
Статья представляет собой обзор зарубежных и отечественных публикаций, посвященных психологическим проблемам, с которыми сталкиваются гомо- и бисексуальные подростки и юноши с девушками, а также особенностям психологической помощи ЛГБ'-подросткам и молодым людям. Авторы поднимают важную проблему уязвимости ЛГБ-подростков и молодых людей в России начала XXI в. Авторы рассматривают особенности социокультурной ситуации, в которой взрослеют ЛГБ-подростки, анализируют факторы риска, которым подвергается ЛГБ-юношество, сопоставляя данные зарубежных и отечественных исследователей, а также защитные факторы, на развитие которых могут быть направлены меры по психологической помощи ЛГБ. К факторам, повышающим риски развития аффективных расстройств, рискованного и суицидального поведения, авторы относят: насилие в семье и отвержение близкими, насилие и отвержение со стороны сверстников, политическую и институциональную гомофобию, травлю, принудительное раскрытие, физическое насилие на почве раскрытия гомосексуальности, стресс меньшинства, интернализованную гомофобию, социальную, эмоциональную и информационную изоляцию. К защитным факторам относятся: доступная объективная и нестигматизирующая информация о гомосексуальности; поддержка других людей, в том числе близких, сверстников, учителей, ЛГБТ-организаций; позитивная эго-идентичность, в том числе гендерная и сексуальная идентичность; доступ к качественной медицинской и психологической помощи. Авторы подчеркивают, что большинство психологических проблем, с которым сталкиваются ЛГБ-подростки, непосредственно не связаны с сексуальностью и сексуальной ориентацией, однако изоляция, в которую попадают ЛГБ-подростки, может существенно обострить свойственные подростковому и юношескому возрасту сложности. В статье выделены общие направления и ключевые особенности психологической работы с ЛГБ-подростками и юношами.
\end{abstract}

Ключевые слова: психологическая помощь, гомосексуальность, бисексуальность, подростковый возраст, ранний юношеский возраст, гомофобия, стресс меньшинства, психическое здоровье ЛГБТИК.

${ }^{1}$ В работе аббревиатура ЛГБ применяется для обозначения людей с гомосексуальным и бисексуальным влечением: геев, лесбиянок и бисексуалов. Мы сократили более привычное обозначение ЛГБТ, включающее трансгендерных людей, так как предмет нашего исследования составило положение в России именно ЛГБ-молодых людей и особенностей их взросления. Приводя ссылки на исследования и рекомендации коллег, мы следовали особенностям описанных выборок, которые могли включать ЛГ, ЛГБ, ЛГБТ и ЛГБТКИА людей, т.е. также людей с интерсексуальной, асексуальной или квир-идентичностью. 


\section{Введение}

Существует широкий массив данных о выраженности среди гомо- и бисексуалов аффективных расстройств, форм рискованного поведения и суицидального поведения (Hatzenbuehler et al., 2010; Kann et al., 2011; Ryana et al., 2015). При этом большинство авторов связывают возникающие психологические сложности ЛГБ-людей не с гомосексуальностью как таковой, а с последствиями социального давления (Кон, 1998; Строкова, 2013; Нагорная, 2009; Ryana et al., 2015). Одной из самых уязвимых групп ЛГБ оказываются люди подросткового и юношеского возраста - 12-20 лет (Kann et al., 2011; Russel, Joyner, 2001; Rothman et al., 2012). Внимание авторов данной статьи сосредоточено именно на этой возрастной группе.

Негативные установки по отношению к гомо- и бисексуалам затрудняют для ЛГБ-подростков формирование позитивной эго-идентичности, могут приводить к стигматизации и маргинализации молодых людей. Признавая важность обозначенного возрастного периода в формировании здоровой личности, мы считаем необходимым учитывать возможные последствия сложившейся социокультурной обстановки в России 2010-х гг. Не менее важно предложить направления работы для смягчения воздействия среды на чувствительную психику ЛГБ-подростков и молодых людей.

Наша статья представляет собой обзор зарубежных и отечественных исследований психологических проблем, с которыми сталкиваются гомо- и бисексуальные подростки и молодые люди. Мы приводим зарубежные и отечественные данные:

- об особенностях отношения к ЛГБ-людям в России и их последствиях для молодых ЛГБ и ЛГБ-подростков;

- о возможных причинах и дополнительных факторах риска суицида и развития психических заболеваний ЛГБ-подростков и молодых людей, а также о факторах и мерах, их предотвращающих;

- о направлениях и особенностях психологической помощи, оказываемой ЛГБ-подросткам и молодежи в России и за рубежом.

\section{Сложности, с которыми сталкиваются ЛГБ-подростки и молодежь в российском обществе}

Ведущая деятельность подростка - общение со сверстниками (Эльконин, 1971). Благодаря общению подростки формируют мировоззрение и самосознание, которые определяют дальнейшее развитие личности. Юношеский возраст - момент осмысления пройденного пути, установления собственных ценностей и принципов (Эриксон, 1996), а также это время для установления отношений и преодоления изоляции. Очень важно то, как строятся отношения подростков и молодежи со сверстниками, родственниками, учителями и преподавателями. Для понимания психологических проблем, возникающих у ЛГБ-подростков и молодых людей, важно знать, каково отношение к гомосексуальному влечению и поведению в их окружении.

В научной картине мира начала XXI в. гомо- и бисексуальность рассматривается как результат эволюции 
и один из вариантов нормального развития сексуальности человека, а ЛГБ-идентичность - как один из возможных видов психосексуальной идентичности (Кон, 1998; Луковицкая, 2003). На сегодняшний день в России отношение к людям, переживающим и реализующим гомосексуальное влечение, скорее отрицательное. По утверждению В.Е. Кагана, однополая любовь и реализующие ее люди оказываются в «ксенофобических и экстремистских проскрипционных списках как то, чего не должно быть, что не имеет права на существование, равно как и те, кто эту любовь исповедуют» (Каган, 1998).

По данным 2013 г., относительное большинство россиян, опрошенных Левада-центром, считают, что «гомосексуализм - это болезнь, которую надо лечить (34\%), 16\% предполагают, что это данная от рождения сексуальная ориентация, 17\% результат совращения и 23\% - плохое воспитание» (Плотко, 2013). Ссылаясь на результаты, мы используем авторскую формулировку вопроса социологов Левада-центра. Слово «гомосексуализм» содержит установку, приравнивающую гомосексуальность к болезни или девиантному поведению. С точки зрения И.С. Кона, у бытовой гомофобии россиян нет оснований в опыте, но она во многом является результатом социально-политической обстановки и подпитывается ориентацией политиков и общественных деятелей на «традиционные ценности» (Кон, 2006). Изменения российского законодательства 2013 г. согласуются с предположениями И.С. Кона о грядущем усилении политической гомофобии. Ряд авторов рассматривают традиционалистские установки как одну из причин гомофобии и трудностей в принятии гомосексуального влечения у человека его близкими (Климова, 2014; Петрова, 2015).

Существуют данные о том, сколь разрушительное влияние на психику ЛГБ-взрослых оказывает существование в условиях дискриминационных законов. М.Л. Хаценбюлер с соавт. сравнили данные о психическом здоровье ЛГБ-пациентов, проживающих в штатах, разрешивших и запретивших однополые браки. Они показали, что в штатах, где существует такой запрет, у ЛГБ чаще проявляются расстройства настроения, генерализованное тревожное расстройство, злоупотребление алкоголем и сопутствующие психиатрические заболевания. В штатах, где такой запрет снят, уровень заболеваемости фиксируется на уровне, не отличающемся от уровня заболеваемости гетеросексуалов (Hatzenbuehler et al., 2010). Авторы считают, что эти данные показывают, что существование в социальной среде с институциональной дискриминацией может ухудшить психическое состояние ЛГБ. По данным исследования И.В. Соболевой и Я.А. Бахметьева, взрослые ЛГБТ, принявшие участие в опросе, не склонны менять свое поведение после введения закона о запрете «пропаганды гомосексуализма». При этом запрет «пропаганды гомосексуализма» заставил ЛГБТ «переопределить свою жизненную стратегию в терминах политической борьбы, а не субкультурной идентичности» (Соболева, Бахметьев, 2014, с. 217).

В России не ведется официального учета преступлений ненависти в 
отношении ЛГБ. Последний отчет о результатах опроса «Российской ЛГБТ-сети» показывает, что негативные установки к людям, испытывающим гомосексуальное влечение, реализуются в поведении. В 2015 г. по сравнению с предыдущими годами возросло число ЛГБТИК, подвергшихся физическому (17\%), психологическому $(60 \%)$ и сексуальному насилию (5\%). Эти показатели впервые повысились за период с 2000 г. Организаторы опроса связывают этот феномен с тем, что в опросе приняло участие больше подростков и молодых взрослых (Ежегодный опрос Российской ЛГБТ-сети..., 2015).

Т. Купер в октябре-ноябре 2013 г. опросила 78 ЛГБТ разного возраста из 15 российских городов, в том числе и несовершеннолетних, пострадавших от насилия или преследования. По ее данным, такие люди «при попытках добиться защиты и правосудия сталкиваются с почти непреодолимыми барьерами, и в итоге гомофобные преступления фактически остаются безнаказанными» (Купер, 2014, с. 67). Лишь немногие потерпевшие представители ЛГБТ-сообщества обращаются в полицию, в то время как полицейские отказываются принимать заявления, перекладывают вину на потерпевших, ведут расследования неохотно и неэффективно, уменьшают наказание нападавшим либо вовсе их отпускают без предъявления обвинений. До суда такие дела практически не доходят. Более того, «сотрудники правоохранительных органов умышленно игнорируют основной мотив нападений, а именно ненависть к ЛГБТ. Даже самые вопиющие случаи гомофобного насилия, [например гей-хантинг ${ }^{2}-T . J$, A.К.], российские правоохранительные органы не квалифицируют как преступления, совершенные на почве ненависти» (Там же), хотя такая квалификация могла бы вызвать более серьезную ответственность для агрессоров.

Р. Джонсон с соавт. анализируют широкий круг источников о психическом здоровье ЛГБТ-студентов колледжей в США и странах Европы (Johnson et al., 2013). Они утверждают, что ЛГБТ-подростки значительно чаще, чем их гетеросексуальные сверстники, сталкиваются с отвержением родителей и друзей, а также с физическим и вербальным насилием. Они часто становятся жертвами буллинга и преследования из-за раскрытия своей сексуальной ориентации, добровольного (каминаута) либо насильственного (аутинга). Это приводит к тому, что даже те молодые люди, которые не подвергались насилию, переезжая в кампус, опасаются за собственную безопасность, если вдруг об их идентичности станет известно окружающим. По данным, приводимым И.С. Коном,

\footnotetext{
${ }^{2}$ Организованное выслеживание мужчин и юношей, подозреваемых в гомосексуальности, с целью шантажа, издевательств, пыток или убийства. Зачастую такие преступления снимаются на видео и полученные ролики выкладываются в социальные сети. В России гей-хантерской деятельностью известны радикальные националистские объединения «Оккупай педофиляй» и «Оккупай геронтофиляй».
} 
20-35\% юношей-геев совершают попытку самоубийства (Кон, 1998). Л. Канн с соавт. в 2011 г. проанализировала данные статистики о здоровье школьников IX-XII классов в США. Выяснилось, что суицидальные риски у учеников выше, если они имели опыт сексуального влечения к людям своего пола или относят себя к ЛГБ. Они более склонны к рискованному поведению, чем их гетеросексуальные сверстники, а также позже обращаются за помощью в ситуации насилия или заражения болезнями, передающимися половым путем (Kann et al., 2011). В отношении российских гомо- и бисексуальных подростков и молодых людей нет развернутых данных.

В 2013 г. Е.А. Климова, основательница проекта «Дети-404», опросила 292 ЛГБТИК-подростков. Из них не задумывались о суициде на почве гомофобии 47.3\%, задумывались о суициде на почве гомофобии $35.6 \%$, совершали попытку суицида $17.1 \%$, из них один раз - $11.6 \%$, несколько раз - 5.5\%. В качестве причины суицидальных мыслей молодые люди указывали внутреннюю гомофобию, принудительное раскрытие сексуальной ориентации, физическое и психологическое насилие со стороны родственников и знакомых (Климова, 2014). В декабре 2014 г. в рамках проекта «Дети-404» стартовал мониторинг самоубийств российских ЛГБТИК-подростков: руководительница направления психологической помощи А.С. Кочеткова начала сбор свидетельств друзей и знакомых погибших. За год было выявлено 26 суицидов молодых людей в возрасте от 14 до 20 лет, подавляющее большинство которых произошли в 2012-2015 гг. Эти данные сложно сопоставить с данными зарубежных исследований, использующих медицинскую статистику о попытках суицида.

По данным проекта «Дети-404», 83.5\% ЛГБТИК-подростков регулярно сталкиваются с дискриминацией на основании сексуальной ориентации. Их сверстники часто прибегают к вербальному и физическому насилию. А родители «игнорируют подростка, не верят ему, запрещают заговаривать о его сексуальной ориентации/гендерной идентичности, не позволяют видеться с любимым человеком, лишают средств связи, считают и называют ребенка больным, извращенцем, педофилом, унижают и оскорбляют, ставят перед невыполнимым выбором: “Или я, или твоя так называемая любовь”, пытаются “лечить” в домашних условиях лекарствами и гормонами, водят по батюшкам и по бабкам, угрожают своим детям психбольницей и даже убийством» (Там же, с. 109). Особенно опасны гомофобное поведение и высказывания учителей, которые, с одной стороны, попустительствуют или даже поощряют травлю в своих классах, а с другой стороны, почти не имеют безопасных возможностей поддержать ЛГБТИК-подростков и оказать необходимую им помощь.

Для молодых ЛГБ высок риск стать жертвой сексуального насилия. Существует замалчиваемая и табуированная проблема - корректирующие изнасилования лесбиянок (КИЛ), где главной группой риска являются молодые девушки и подростки. Название «корректирующие» происходит от основного намерения насильников либо людей, состоящих 
с насильниками в сговоре, - «вылечить от болезни/греха», «исправить с помощью нормального мужика», «наказать за лесбийские глупости». А.С. Кочеткова («Дети-404») интервьюирует пострадавших от КИЛ и их знакомых с февраля 2014 г., на данный момент установлены и описаны 22 случая, большинство из них имело место в период с 2010 по 2015 г.

У КИЛ есть общие черты с преступлениями против половой неприкосновенности женщин вообще. Так, чаще всего насильником оказывается знакомый мужчина, питающий к молодой лесбиянке сексуальный интерес, а также характерен предшествующий изнасилованию период сталкинга ${ }^{3}$, который зачастую одобряется родственниками и друзьями девушки вне зависимости от того, знают ли окружающие о ее ориентации. В ряде описанных свидетельств КИЛ совершают сами родственники молодой лесбиянки либо же члены семьи кооперируются и действуют совместно с будущим насильником, что может являться формой сводничества девушки с «хорошим мальчиком» (в том числе и вести к принудительному браку) или быть разовым проявлением родительской воли без матримониальных намерений.

В интервью описаны КИЛ, которые можно трактовать как преступ- ления ненависти, когда насильниками являются лесбофобные группы школьников, студентов или сотрудники полиции. Реакцией родственников жертв на произошедшее в основном является обвинение жертвы. В том числе получены три свидетельства о неквалифицированном сопровождении психологов и учителей, а также об отвержении со стороны священнослужителей, к которым жертвы КИЛ обратились за помощью. После этого неудачного опыта у всех троих девушек усилилась отчужденность и появились суицидальные мысли. Ни одна из жертв КИЛ не обращалась в полицию после случившегося, находясь в угнетенном состоянии, опасаясь давления семьи, угроз насильника и новых унижений во время следствия.

Можно заключить, что молодые российские ЛГБ оказываются в условиях, с одной стороны, нарастающей гомофобии, с другой стороны, поляризации позиций сочувствующих и борющихся с ЛГБ.

\section{Психологическая уязвимость}

Д. Дейвис утверждает, что большинство подростков, обнаруживая в себе гомосексуальное влечение и реализуя гомосексуальное поведение, переживают стресс. От подобного

\footnotetext{
${ }^{3}$ Преследование, навязчивое и нежелательное внимание. Традиционная культура романтического ухаживания нормализует сталкинг, исходя из гендерных стереотипов, предписывая трактовать женский отказ как признак порядочности («нет» = церемониальный ответ, чтобы девушку нельзя было осудить за «легкодоступность»), рассудительности («нет»= «я подумаю и сравню с другими кандидатурами») или игры-флирта («нет»= «да»). В свою очередь традиционное культурное требование к мужчине в ответ на отказ - воспринимать его как вызов и повод к соревнованию с потенциальными конкурентами, что требует настойчивой и оригинальной экспансии.
} 
стресса страдают не только гомо- и бисексуальные подростки, так как 20-30\% гетеросексуальных юношей и 5-10\% девушек имеют гомосексуальный опыт. У многих людей сексуальность не является чем-то окончательно определенным и может меняться в течение жизни (Дейвис, 2001). Процесс сексуальной идентификации может быть сильно затруднен в условиях социального давления, которое препятствует формированию здоровой сексуальной идентичности, как у гомо-, би-, так и у гетеросексуальной молодежи.

Д. Дейвис связывает большинство проблем молодых ЛГБ с изоляцией и выделяет в ней три аспекта. Остановимся на каждом из них.

1. Социальная изоляция возникает в результате опыта отвержения сверстниками и близкими. Не получая принятия и подвергаясь травле, ЛГБ-подростки не решаются на сближение с людьми. Как пишет И.С. Кон, «юность - вообще довольно одинокий возраст, но никто не бывает так одинок, как гомосексуальные подростки» (Кон, 1998, c. 402). Не во всех городах существуют ЛГБТ-организации и комьюнити-центры, открытые для общения с подростками и молодыми людьми, так как возможность их интеграции затрудняется существующим российским законодательством. В таких условиях альтернативой офлайнсообществ становятся Интернет-проекты и социальные сети. Однако эта стратегия также имеет свои минусы: например, в условиях виртуальной анонимности у подростка гораздо выше риск столкнуться с гей-хантерами, выдающими себя за ЛГБТ, чтобы склонить интересующего их человека к подставному свиданию, где и происходит гомофобное нападение.

ЛГБ-подростки часто обнаруживают отличие от сверстников в детстве, еще до периода полового созревания, в результате чего им сложно интегрироваться в социум. При попытках интеграции в общество преобладающих гетеросексуалов у людей с отличной от них сексуальной ориентацией часто развиваются две психологические особенности: интернализованная гомофобия и стресс меньшинства.

Интернализованная гомофобия является результатом усвоения социальных гомофобных установок. По данным опросов проекта «Дети-404», ЛГБТИК-подростки часто долго не принимают свою сексуальную ориентацию, отрицают или борются со своей гендерной ненормативностью. Многие из них в начале становления идентичности «ненавидели себя, считали себя больными, ненормальными, неполноценными, уродами. Некоторые пытались самостоятельно переделаться, вылечиться - но безуспешно» (Климова, 2014, с. 29). Среди причин такого состояния опрошенные указывали: давление друзей, семьи, окружения, общества в целом (которое продолжает относиться к гомосексуальности как к болезни и аномалии, хотя современная наука это не подтверждает); одиночество («таких как я больше нет»); недостаток или отсутствие адекватной информации о том, что с ними происходит; религиозные причины.

Понятие «стресс меньшинства» введено Вирджинией Брукс. Основной причиной этого состояния «является наделение статусом отсталой 
и малоценной определенной группы населения на основе расы, этнического происхождения, болезни, ограниченных физических возможностей, социосексуальных предпочтений и т.д., что влечет за собой негативные последствия для жизни и здоровья человека. В случае гомосексуальных людей проблема состоит в сексизме, гетеросексизме и гомофобии, глубоко укоренившихся в культуре общества» (Нагорная, 2009, c. 24). Стресс меньшинства является следствием социальной изоляции и одновременно поддерживает ее, не позволяя полноценно включиться ни в большой социум носителей гомофобных и гетеросексистских установок, ни в сообщества ЛГБТ. Особенно тягостным он может стать для подростка, для которого одним из важных вызовов является построение позитивной социальной идентичности. Диссертационное исследование Е.В. Зиновьевой показало, что позитивная Я-концепция молодых российских лесбиянок устанавливается на противопоставлении гендерному стандарту (Зиновьева, 2007). Это согласуется с утверждением Д. Дейвиса о том, что молодым ЛГБ бывает сложно найти позитивный социальный эталон, в результате чего они могут развивать вычурное либо социофобное, а иногда даже антисоциальное поведение (Дейвис, 2001).

2. Эмоциональная изолячия связана с необходимостью скрывать свои сексуальные предпочтения и влечения от родственников и близких (Там же). Переживающие эмоциональную изоляцию молодые ЛГБТ вынуждены либо подавлять свою сексуальность, либо существовать в двойном мире: для родителей они изображают гетеросексуальных юношей или девушек, но при этом переживают первые гомосексуальные влюбленности. В обоих случаях им сложно найти человека, с которым можно поделиться важными переживаниями.

По мнению К.Р. Кричер с соавт., сокрытие сексуальной ориентации требует постоянных психических усилий, что в конечном итоге приводит к трудностям в установлении доверительных отношений, снижению когнитивных функций, ухудшению психического и физического здоровья (Critcher, Ferguson, 2014). По данным Е.Ф. Ротман с соавт., у гомо- и бисексуальных женщин отсутствие открытости перед родителями коррелирует с более высоким уровнем рискованного поведения (Rothman et al., 2012). Опрос Е.В. Зиновьевой показал, что лишь $34 \%$ гомосексуальных женщин решаются открыться перед родителями (Зиновьева, 2007). По мнению Д.А. Андронова, не решаясь на самораскрытие, российские геи лишаются семейной поддержки и принятия как одного из важнейших копинг-ресурсов человека (Андронов, 2009).

Альтернативой эмоциональной изоляции является камин-аут. Но раскрытие сексуальной ориентации перед семьей для подростка и юноши представляет собой риск. С одной стороны, из-за ситуации эмоциональной и материальной зависимости совершающий камин-аут подросток может оказаться без важных опор в жизни, крыши над головой, подвергнуться физическому, в том числе сексуальному, или вербальному насилию (Климова, 2014). 
Современные данные показывают, что негативная реакция близких на раскрытие сексуальной ориентации коррелирует с депрессией, заниженной самооценкой и общим снижением качества жизни ЛГБ (Ryana et al., 2015). С другой стороны, существует целый ряд исследований, демонстрирующих преимущества открытой жизни.

Отчасти выходом является камин-аут в сети Интернет. Социальные сети можно рассматривать как виртуальную социальную среду, которая одновременно является полем для формирования, проявления и предъявления своей социальной идентичности, в том числе гендерной и сексуальной (Асмолов, Асмолов, 2010; Изотова, 2012; Остапенко, 2004). В этом контексте особое значение имеет проект «Дети-404», который создает безопасное онлайнпространство для прямого высказывания подростков и молодых ЛГБТИК.

3. Условия взросления российских ЛГБ осложняются когнитивной изолящией, так как молодые люди часто лишены возможности получать достоверную информацию о гомосексуальности и однополых отношениях. Согласно статье 6.21 КоАП РФ, «распространение информации, направленной на формирование у несовершеннолетних нетрадиционных сексуальных установок, привлекательности нетрадиционных сексуальных отношений, искаженно$2 о$ представления о сочиальной равноценности традиционных и нетрадиционных сексуальных отношений, либо навязывание информации о нетрадиционных сексуальных отношениях, вызывающей интерес к таким отношениям» является незаконным. Таким образом, подросток оказывается огражден от информации о гомосексуальности, направленной на формирование позитивного самоотношения ЛГБ.

В странах с более либеральным законодательством часто возникают проблемы с недостаточным вниманием к особенностям ЛГБ-отношений в школьных курсах сексуального образования. Так, Э. Пингел с соавт. утверждают, что необходима существенная трансформация существующих курсов и создание специализированных программ сексуального образования для ЛГБТ-подростков (Pingel et al., 2013). Участвовавшие в ее опросе взрослые утверждали, что в юности у них не было возможности получить необходимую информацию, они часто рисковали своим здоровьем, опираясь на советы знакомых и непроверенную информацию. Недоступность объективной и нестигматизирующей информации о гомосексуальности Д. Дейвис рассматривает как одну из возможных причин осложнений формирования сексуальной и гендерной идентичности молодых ЛГБ (Дейвис, 2001). Не имея информации из достоверных источников, подростки пытаются компенсировать ее сведениями, получаемыми от сверстников, и поисками в Интернете. Преимущественное доверие сверстникам и публикациям Интернета свойственно не только ЛГБТ-подросткам, однако, по данным Дж.К. Маджи с соавт., молодые ЛГБТ часто стесняются обратиться за информацией о сексуальном здоровье и поведении к специалистам и доверяются Интернету (Magee et al., 2012). 
Изоляция ЛГБ-молодежи приводит к чувству брошенности. Подростки воспринимают себя как бремя для близких людей, а также болезненно переживают отвержение семьей. Таким образом, изоляция погружает подростка в эмоциональное состояние, которое, по мнению T.С. Павловой и Г.С. Банникова, может стать одним из факторов суицидального поведения (Павлова, Банников, 2013).

\section{Защитные факторы}

Существуют ли факторы, которые могут снять последствия стресса меньшинства и интернализованной гомофобии, снизить вероятность суицида, развития эмоциональных расстройств и рискованного поведения у ЛГБ-подростков и молодых людей?

ЛГБТ-подростки, принявшие участие в опросе проекта «Дети-404», чаще всего так отвечали на вопрос, что им помогло принять себя:

1) доступная информация;

2) осознание своего неодиночества;

3) помощь другого человека (Климова, 2014).

Можно предположить, что ключевое значение для них имеет преодоление изоляции.

Важную роль в нейтрализации стресса меньшинства играют личные характеристики человека и социальная поддержка (Нагорная, 2009). Источником этой поддержки могут быть родители, друзья, партнеры, ЛГБТКИА-сообщества и другие люди. Отвержение, упреки и попытки переделать оказывают противоположный эффект. Е.В. Петрова утверждает, что степень принятия, кото- рую родители готовы дать своим ЛГБ-детям, зависит, в частности, от социально-политической ситуации в стране и собственных установок родителей: «Cramer and Roach (1988) получили данные о том, что родители с жесткой, традиционной системой ценностей по отношению к сексуальному поведению могут изменить свои взгляды, если речь идет об их сыне. С другой стороны, родители, имеющие либеральные установки, далеко не всегда готовы сразу воспринять положительно новость о гомо-/бисексуальности своего ребенка» (Петрова, 2015, с. 4).

Боясь признаться родителям или друзьям, подростки и молодые люди часто ищут социальную поддержку в Интернете. В 2010-2011 гг. М.Л. Ибарра с соавт. провели анкетирование 5542 американских девушек и юношей об их поведении в Интернете и реальной жизни. Основной задачей авторов было сравнить поведение в сети и в реальной жизни гетеросексуального и ЛГБТ-юношества. Исследование показало бо́льшую склонность молодых ЛГБТ получать социальную поддержку через Интернет. По данным М.Л. Ибарра, получая онлайн-поддержку, молодые ЛГБТ решаются более открыто действовать в ближайшем окружении, используя Интернет как своего рода репетицию самораскрытия. Это поведение сопряжено с рядом рисков, в том числе ЛГБТ-молодые люди чаще подвергаются онлайнтравле и сексуальным домогательствам, что может свести на нет положительный эффект от полученной поддержки (Ybarra et al., 2015). Очевидно, что ЛГБ-подростки и молодые люди нуждаются в построении 
более безопасного виртуального пространства, которое могло бы решить часть их сложностей в реальной жизни. Социальная поддержка может быть воспринята только в том случае, когда молодой человек открыт тем, кто его поддерживает. Современные данные показывают, что совершенный камин-аут играет важную роль в дальнейшей жизни ЛГБ-молодых людей. Дж.Г. Косчив с соавт. проанализировали данные успеваемости и благополучия более 7000 ЛГБТ студентов второго года обучения. Их результаты показали, что открытость положительно коррелирует с высокой самооценкой и отрицательно - c уровнем депрессии. Она связана также с большей степенью виктимизации, которая напрямую сказывается на успеваемости и уровне благополучия студентов. Виктимизация в разной степени проявлялась в зависимости от дружественности окружения к ЛГБТ. Таким образом, у обследованных студентов положительные последствия самораскрытия практически полностью нивелировались результатами виктимизации, однако в другой социокультурной ситуации результат может отличаться (Kosciw et al., 2015). Для преодоления виктимизации и интернализованной гомофобии важную роль играет способность к самопрощению и самопринятию, которая в том числе формируется из опыта прощения и принятия близкими людьми. Особенно это важно в случае с ЛГБТИК, разделяющими взгляды больших религий. По данным Дж. Льюиса, готовность простить себя отрицательно коррелирует с чувством изоляции, одиночеством и чувством вины (Lewis et al., 2011).
М.Л. Хатценбюлер с соавт. указывают на огромное значение доброжелательного школьного климата для успеваемости и психического здоровья ЛГБ-подростков (Hatzenbuehler et al., 2014). Создание подобного климата предполагает направленные действия со стороны администрации школы и учителей, которым рекомендуется пройти дополнительную подготовку для работы с ЛГБ. Р.Б. Джонсон с соавт., подготовившие руководство по предотвращению суицидов среди ЛГБТ-студентов, проанализировали большое количество источников, посвященных защитным факторам для ЛГБТ-учеников в американской системе образования. Они подчеркивают значение:

1) связи с семьей,

2) поддерживающего отношения взрослых,

3) безопасности в школе (в том числе отсутствии случаев буллинга, доверительности и конфиденциальности отношений учитель - ученик),

4) наличию в регионе ЛГБТ-организаций, реализующих образовательные программы,

5) позитивной сексуальной или гендерной идентичности,

6) доступу к качественным услугам системы охраны психического здоровья (Johnson et al., 2013).

\section{Как помочь?}

Часть возникающих у ЛГБ-подростков и молодежи психологических проблем является следствием того, что они живут в преимущественно гетеросексуальном обществе, определяющем их инаковость, а также позволяющем различные формы дискриминации в отношении 
ЛГБТИК. Описаны специфические характерные для ЛГБТИК-людей сложности, с которыми они обращаются к психологам:

1) принятие себя и своей идентичности, интернализованная гомофобия, преодоление стресса меньшинства;

2) различные аспекты совершения камин-аута;

3) партнерские отношения (Сабунаева, 2009).

Часть этих проблем характерна для подросткового и младшего юношеского возраста в целом: формирование идентичности, сложности в первых отношениях, отчуждение. Молодые люди могут оказаться в социальной, эмоциональной и информационной изоляцией по причинам, не связанным с сексуальной ориентацией. Однако у молодых ЛГБ очень мало возможностей ее избежать. Иными словами, «потребность гомосексуалов в психологической помощи определяется не фактом сексуальной ориентации, а фактом их положения в обществе» (Там же, с. 30). Д. Дейвис подчеркивает, что работа с ЛГБ-молодежью - это поддержка взрослеющей самостоятельной личности и сопровождение в преодолении изоляции (Дейвис, 2001). Особенно важными тут являются уважение к чувствам, опыту и праву выбора молодого человека (Лапшина, 2015).

Условия консультирования ЛГБподростков и молодежи требуют корректировки с учетом социальной ситуации, в которой они живут или могут оказаться. Организационные условия - времени, оплаты и труда консультанта - незначительно отличаются от обычных условий, диктуе- мых профессиональной этикой. Однако, как отмечает М.Л. Сабунаева, важно, чтобы место консультации было доступно и безопасно, чтобы его можно было посетить, не раскрыв себя. Часто ЛГБ-подростки и юноши могут оказаться без средств к существованию и нуждаться в бесплатной психологической помощи. Необходима организация специальных служб, готовых оказывать бесплатную психологическую помощь ЛГБ-молодежи. Примером такой службы может быть «виртуальный кризисный центр» проекта «Дети-404», который предоставляет бесплатные психологические консультации, информационную помощь, а также осуществляет посредничество между потерпевшими и ЛГБТ-организациями. Бесплатная психологическая помощь в России доступна:

1) через единую общероссийскую линию телефонов доверия для детей, подростков и их родителей (профессиональная анонимная и бесплатная помощь, в части регионов - круглосуточная);

2) по горячей линии российской ЛГБТ-сети для лесбиянок, геев, бисексуалов, трансгендеров и их родных (юридическая и психологическая помощь, круглосуточно);

3) в центрах социально-психологической помощи для детей и подростков (оказывают бесплатную помощь детям и семьям, оказавшимся в трудной жизненной ситуации) (Климова, 2014).

В современных условиях каждый из этих трех путей получения психологической помощи ЛГБТ-подростком сопряжен с риском неудовлетворительного обслуживания и/или 
отказа. При работе с ЛГБ-подростками и молодежью особенно важна конфиденциальность, поскольку в гомофобной среде аутинг может поставить под угрозу жизнь и социальное благополучие молодого человека.

Особое значение при консультировании ЛГБ-подростков и юношей имеют психологические условия, определяющие готовность консультанта и клиента к работе (Дейвис, 2001; Сабунаева, 2009). Согласно этическому кодексу, «психолог с равным уважением относится к людям вне зависимости от их возраста, пола, сексуальной ориентации, национальности, принадлежности к определенной культуре, этносу и pace, вероисповедания, языка, социально-экономического статуса, физических возможностей и других оснований», однако усвоенные гомофобные установки могут мешать психологу оказывать эффективную помощь ЛГБ-клиенту. Особое значение имеет добровольность взаимодействия при консультации, поскольку в случае с ЛГБ-подростками к психологу могут обращаться родители с запросом «сделать нормальным их ребенка» (Этический кодекс психолога, 2012).

Важными являются меры по развитию защитных факторов для ЛГБ и гетеросексуальных подростков. Они могут включать:

- разработку ясной системы сексуального образования для подро- стков, раскрывающей эволюционную природу и иные аспекты различных форм сексуальности ;

- развитие и поддержание безопасной обстановки в школах и вузах, в том числе меры по профилактике травли и развитию толерантности как важного качества современной личности;

- развитие доступной для подростков и юношей системы психологической (в том числе бесплатной) помощи;

- создание безопасной и доступной системы распространения достоверной информации о сексуальности и сексуальном здоровье для целевой аудитории;

- подготовку специалистов для работы с ЛГБ-подростками и юношами, а также переподготовку учителей и работников образования;

- дальнейшее изучение вопросов включенности-изолированности, психологических факторов, определяющих психическое благополучие ЛГБ-подростков в России.

\section{Заключение}

Согласно данным опросов активистских организаций, российские ЛГБ-подростки и молодые люди живут в условиях распространенности гомофобных установок, угрозы физического и вербального насилия, различных форм дискриминации, которые, согласно зарубежным данным, могут привести к ухудшению

\footnotetext{
${ }^{4}$ Основные принципы и возможные формы включения информации об однополых отношениях в учебные программы описаны в работе, доступной в электронном приложении к выпуску Scientific Educational Intervention: «Same-Sex Mating \& Nature», Ali Jahromi, Senior Laboratory Coordinator. New York University, 2016. January 31.
} 
психического и физического здоровья. Однако для построения более объективной картины необходим сбор статистических данных, в том числе медицинской статистики и статистики правоохранительных органов.

ЛГБ-подростки и молодые люди в большей степени, чем их гетеросексуальные сверстники, склонны к суицидальному и рискованному поведению, развитию аффективных нарушений.

Частыми психологическими сложностями ЛГБ-подростков и молодых людей являются: стресс меньшинства; интернализованная гомофобия; социальная, эмоциональная и когнитивная изоляция; последствия насилия и дискриминации.

Реализация психологической помощи ЛГБ-молодежи имеет специфику и требует дополнительной подготовки психологов и помогающих практиков.
Ситуация, сложившаяся в России в 2010-е гг., бросает вызов психологам, помогающим практикам и ставит нас перед сложным этическим выбором. Нам кажется необходимым продолжать развитие психологических исследований и работы с ЛГБ-подростками и юношами. Недостаток психологических научных данных приводит к распространению опасных мифов, поддерживающих гомофобные установки, такие, как «контагиозность» или «пропаганда» гомосексуальности, а также препятствует проведению экспертизы в соответствии с запросами суда о «пропаганде нетрадиционных отношений». Для построения системы квалифицированной помощи ЛГБ необходимы эмпирические исследования, которые позволят выявить специфику проблем и ресурсов российской ЛГБмолодежи, а также программа подготовки специалистов, готовых оказывать помощь ЛГБ.

\section{Литература}

Андронов, Д. А. (2009). Особенности совладающего (копинг) поведения в трудных жизненных ситуациях у мужчин с гомосексуальной идентичностью. Наука о человеке: гуманитарные исследования, 3, 89-95.

Асмолов, А. Г., Асмолов, Г. А. (2010). От Мы-медиа к Я-медиа: трансформации идентичности в виртуальном мире. Вестник Московского университета. Серия 14. Психология, 1, 3-21.

Дейвис, Д. (2001). Психотерапевтическая работа с молодыми людьми. В кн. Д. Дейвис и Ч. Нил (Ред.), Розовая психотерапия. Руководство по работе с сексуальными меньшинствами (с. 222-249). СПб.: Питер.

Ежегодный опрос Российской ЛГБТ-сети показал особенную уязвимость группы ЛГБТ-подростков и молодежи (2015). Режим доступа: https:/ www.lgbtnet.ru/ru/content/ezhegodnyy-oprosrossiyskoy-lgbt-seti-pokazal-osobennuyu-uyazvimost-gruppy-lgbt-podrostkov-i

Зиновьева, Е. В. (2007). Особенности Я-конщепции женщин нетрадиционной сексуальной ориентации (Автореферат кандидатской диссертации, Санкт-Петербургский государственный университет, Санкт-Петербург). 
Изотова, Е. И. (2012). Особенности самопредъявления подростков с разной степенью сформированности идентичности. Психологические исследования, 5(26), 9. Режим доступа: http://psystudy.ru/ index.php/num/2012v5n26/764-izotova26.html

Каган, В. Е. (1998). Возможность выйти на солнечный свет. Психологическая газета, 9(36), 31-32.

Климова, Е. А. (2014). Дети-404. ЛГБТ-подростки: В стенах молчания. Нижний Тагил.

Кон, И. С. (1998). Лунный свет на заре. Лики и маски однополой любви. М.: Олимп; АСТ.

Кон, И. С. (2006). Секс и меньшинства: Как гомофобия становится ксенофобией. Новое время, $15,32-35$.

Купер, Т. (2014). Лищензия на травлю. Гомофобное насилие и преследование ЛГБТ-сообщества в России. Режим доступа: https://www.hrw.org/ru/report/2014/12/15/267949

Лапшина, Т. Н. (2015, 10 февраля). Психологическая работа с подростком с отличающейся от традиционной сексуальной ориентацией. Психологическая газета. Режим доступа: http://www.psy.su/feed/4481/

Луковицкая, Е. Г. (2003). Восприятие гомосексуальности. В кн. И. Н. Клецина (Ред.), Практикум по гендерной психологии (с. 415-426). Санкт-Петербург: Питер.

Нагорная, Н. П. (2009). «Стресс меньшинства». В кн. Л. Гейдар (сост.), М. Андрущенко (Ред.), Социальная работа с людьми, практикующими однополье сексуальные отношения: Теория. Методики. Лучшие практики (с. 24-26). Киев: Международный Альянс по ВИЧ/СПИД в Украине.

Остапенко, И. А. (2004). Гендерная идентичность и самопрезентация в Интернеткоммуникации: Социально-философский анализ (Кандидатская диссертация, Ростовский государственный университет, Ростов-на-Дону).

Павлова, Т. С., Банников, Г. С. (2013). Современные теории суицидального поведения подростков и молодежи. Психологическая наука и образование рsyedu.ru, 4. Режим доступа: http://psyjournals.ru/psyedu_ru/2013/n4/65717.shtml

Петрова, Е. В. (2015). Теоретическое исследование факторов отношения родителей к взрослым детям с гомо-/бисексуальной идентичностью. Ученые записки: электронный научный журнал Курского государственного университета, 1(33). Режим доступа: http://cyberleninka.ru/article/n/teoreticheskoe-issledovanie-faktorov-otnosheniya-roditeley-k-vzroslym-detyam-s-gomobiseksualnoy-identichnostyu

Плотко, М. (2013, 12 марта). Страх другого. Проблема гомофобии в России. Демоскоn Weekly. URL: http://demoscope.ru/weekly/2013/0549/opros07.php

Сабунаева, М. Л. (2009). Основы оказания психологической помощи гомосексуалам. В кн. Л. Гейдар (сост.), М. Андрущенко (ред.), Социальная работа с людъми, практикующими однополые сексуальные отношения: Теория. Методики. Лучшие практики (с. 30-36). Киев: Международный Альянс по ВИЧ/СПИД в Украине.

Соболева, И. В., Бахметьев, Я. А. (2014). «Меня как будто вытолкали за ворота»: реакция ЛГБТ на запрет «пропаганды гомосексуализма». Журнал исследований соииальной политики, 12(2), $217-232$.

Строкова, С. С. (2013). Изменение модели гомосексуальности в психодинамическом подходе (обзор зарубежных исследований). Современная зарубежная психология, 2(3), 81-92. Режим доступа: http://psyjournals.ru/jmfp/2013/n3/63508.shtml

Эльконин, Д. Б. (1971). К проблеме периодизации психического развития в детском возрасте. Вопросы психологии, 4, 6-20.

Эриксон, Э. (1996). Идентичность: юность и кризис. М.: Прогресс. 
Этический кодекс психолога (2012). Режим доступа: http://pпо.pф/rpo/documentation/ethics.php

Critcher, C. R., \& Ferguson, M. J. (2014). The cost of keeping it hidden: Decomposing concealment reveals what makes it depleting. Journal of Experimental Psychology: General, 143(2), 721-735.

Hatzenbuehler, M. L., Mark, L., Birkett, M., Van Wagenen, A., \& Meyer, I. H. (2014). Protective school climates and reduced risk for suicide ideation in sexual minority youths. American Journal of Public Health, 104(2), 279-286.

Hatzenbuehler, M. L., McLaughlin, K. A., Keyes, M., Katie, A., Katherine, M., \& Hasin, D.S. (2010). The impact of institutional discrimination on psychiatric disorders in lesbian, gay, and bisexual populations: a prospective study. American Journal of Public Health, 100(3), 452-459.

Johnson, R. B., Oxendine, S., Taub, D. J., \& Robertson, J. (2013). Suicide prevention for LGBT students. New Directions for Student Services. Special Issue: Preventing College Student Suicide, 141, $55-69$.

Kann, L., O’Malley Olsen, E., McManus, T., Kinchen, S., Chyen, D., Harris, W. A., \& Wechsler, H. (2011). Sexual identity, sex of sexual contacts, and health-risk behaviors among students in grades 9-12 - Youth Risk Behavior Surveillance, Selected Sites, United States, 2001-2009. Surveillance Summaries, 60(SS07), 1-133.

Kosciw, J. G., Palmer, N. A., \& Kull, R. M. (2015). Reflecting resiliency: openness about sexual orientation and/or gender identity and its relationship to well-being and educational outcomes for LGBT students. American Journal of Community Psychology, 55(1-2), 167-178.

Lewis, J., Chwee-Lye, C., Logan, M. A., \& Vosvick, M. (2011). Predictors of forgiveness of Self in LGBT adults: Coming out, guilt, and loneliness. Paper presented at the APHA 139th Annual Meeting and Exposition, Washington, DC. Retrieved from https://apha.confex.com/apha/139am/webprogram/ Paper243890.html

Magee, J. C., Bigelow, L., Dehaan, S., \& Mustanski, B. S. (2012). Sexual health information seeking online: a mixed-methods study among lesbian, gay, bisexual, and transgender young people. Health Education and Behavior, 39(3), 276-289.

Pingel, E. S., Thomas, L., Harmell, Ch., \& Bauermeister, J. (2013). Creating comprehensive, youth centered, culturally appropriate sex education: What do young gay, bisexual and questioning men want? Sex Res Social Policy, 10(4). Retrieved from http://www.ncbi.nlm.nih.gov/pmc/articles/ PMC3862289/

Rothman, E. F., Sullivan, M., Keyes, S., \& Boehmer, U. (2012). Parents' supportive reactions to sexual orientation disclosure associated with better health: Results from a population-based survey of LGB adults in Massachusetts. Journal of Homosexuality, 59(2), 186-200.

Russell, S. T., \& Joyner, K. (2001). Adolescent sexual orientation and suicide risk: Evidence from a national study. American Journal of Public Health, 91(8), 1276-1281.

Ryana, W. S., Legateb, N., \& Weinstein, N. (2015). Coming out as lesbian, gay, or bisexual: The lasting impact of initial disclosure experiences. Self and Identity, 14(5), 549-569.

Ybarra, M. L., Mitchell, K. J., Palmer, N. A., \& Reisner, S. L. (2015). Online social support as a buffer against online and offline peer and sexual victimization among U.S. LGBT and non-LGBT youth. Child Abuse and Neglect, 39, 123-136. 


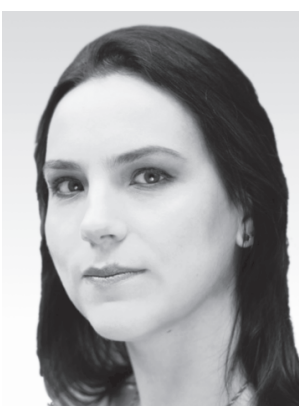

Лапшина Татьяна Николаевна - доцент кафедры общей психологии и психологии развития, ГБОУ ВО МО «Академия социального управления», кандидат психологических наук.

Сфера научных интересов: аффективная психофизиология, психология эмоций, эмоциональный интеллект, психология образования, психология в школе, психологическое консультирование, экзистенциальная психотерапия, гештальттерапия, телесноориентированная психотерапия

Контакты: tatyana.lapshina@gmail.com

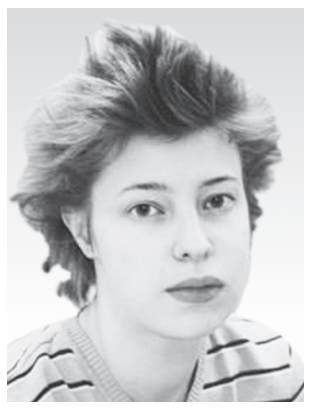

Кочеткова Анна Сергеевна - волонтер, руководитель направления психологической помощи проекта «Дети-404».

Сфера интересов: психология способностей и одаренности, дифференциальная психофизиология, гендерная психология, психология травмы, психология памяти.

Контакты: hana.kochetkovavaneyan@gmail

\title{
Mental Health of LGB Adolescence and Youth as a Challenge to Russian Psychology
}

\author{
Tatyana N. Lapshina ${ }^{\mathrm{a}}$, Anna S. Kochetkova ${ }^{\mathrm{b}}$
}

${ }^{a}$ Social Management Academy of Moscow Region, $3 / 5$ Yeniseiskaya str., Moscowe, 129344, Russian Federation.

${ }^{b}$ Independent researcher.

\begin{abstract}
The article presents a review of foreign and domestic publications on psychological problems of homo- and bisexual adolescents and youth, as well as on characteristics of psychological counseling of LGB-adolescents and youth. The authors bring up an important concern of vulnerability of LGB-adolescents and young people in Russia in the XXI century. The authors discuss characteristics of the sociocultural situation, in which LGB-adolescents come to age, analyze risk factors to which LGB-youth is exposed, comparing data of foreign and domestic research, as well as protective factors, the development of which may be secured by psychological counseling of LGB. According to the authors, the factors that heighten risks of development of affective disorders, risky and suicidal behaviors are violence in family and reprobation of family members, violence and reprobation of peers, political and institutional homophobia, bullying, forced coming out, physical violence related to coming out, minority stress, internalized homophobia, social, emotional and informational isolation. Protective factors are open objective and non-stigmatizing information about homosexuality, support of other people, including family members, peers, teachers, LGBT-organizations, positive self-identity, including gender and sexual identity, access
\end{abstract}


to quality medical and psychological help. The authors emphasize that majority of psychological problems, encountered by LGB-adolescents, do not related directly to sexuality and sexual orientation, but isolation, which accompanies LGB-adolescents, may significantly escalate problems, which are typical for adolescent and young age. The article describes general trends and key characteristics of psychological counseling of LGB-adolescents and youth.

Keywords: psychological counseling, homosexuality, bisexuality, adolescence, youth, homophobia, minority stress, psychic health in LGBTIK.

\section{References}

Andronov, D. A. (2009). Distinctive features of difficult life situations experienced by homosexual men. Science of the Person: Humanitarian Researches, 3, 89-95.

Asmolov, A. G., \& Asmolov, G. A. (2010). From We-media to I-media: Identity transformations in the virtual world. Vestnik Moskozskogo Universiteta. Seriya 14. Psikhologiya, 1, 3-21.

Critcher, C. R., \& Ferguson, M. J. (2014). The cost of keeping it hidden: Decomposing concealment reveals what makes it depleting. Journal of Experimental Psychology: General, 143(2), 721-735.

Davies, D. (2001). Psikhoterapevticheskaya rabota s molodymi lyud'mi [Psychotherapeutic work with young people]. In D. Davies and C. Neal (Eds.), Rozovaya psikhoterapiya. Rukovodstvo po rabote s seksual'nymi men'shinstvami [Pink psychotherapy: A guide for work with sexual minorities] (pp. 222-249). Saint Petersurg: Piter. (Transl. of: Davies, D., \& Neal, C. (Eds.). (1996). Pink therapy: A guide for counsellors and therapists working with lesbian, gay and bisexual clients. Buckingham, UK/Philadelphia, PA: Open University Press).

Elkonin, D. B. (1971). K probleme periodizatsii psikhicheskogo razvitiya v detskom vozraste [On the problem of periodization of psychic development in childhood]. Voprosy Psikhologii, 4, 6-20.

Erikson, E. (1996). Identichnost': yunost' $i$ krizis [Identity: youth and crisis]. Moscow: Progress. (Transl. of: Erikson, E. H. (1968). Identity, youth and crisis. New York: W. W. Norton Company).

Eticheskii kodeks psikhologa [Ethical code of psychologist]. (2012). Retrieved from http://рпо.pф/rpo/documentation/ethics.php

Ezhegodnyi opros Rossiiskoi LGBT-seti pokazal osobennuyu uyazvimost' gruppy LGBT-podrostkov i molodezhi [Annual survey of the Russian LGBT-network showed marked vulnerability of the group of LGBT-adolescents and youth]. (2015). Retrieved from https://www.lgbtnet.ru/ru/content/ezhegodnyy-opros-rossiyskoy-lgbt-seti-pokazal-osobennuyu-uyazvimost-gruppy-lgbt-podrostkov-i

Hatzenbuehler, M. L., Mark, L., Birkett, M., Van Wagenen, A., \& Meyer, I. H. (2014). Protective school climates and reduced risk for suicide ideation in sexual minority youths. American Journal of Public Health, 104(2), 279-286.

Hatzenbuehler, M. L., McLaughlin, K. A., Keyes, M., Katie, A., Katherine, M., \& Hasin, D.S. (2010). The impact of institutional discrimination on psychiatric disorders in lesbian, gay, and bisexual populations: a prospective study. American Journal of Public Health, 100(3), 452-459.

Izotova, E. I. (2012). Features of self-representation in teenagers with different levels of identity development. Psikhologicheskie Issledovaniya, 5(26), 9. Retrieved from http:/psystudy.ru/index.php/ eng/2012v5n26e/752-izotova26e.html

Johnson, R. B., Oxendine, S., Taub, D. J., \& Robertson, J. (2013). Suicide prevention for LGBT students. Nerw Directions for Student Services. Special Issue: Preventing College Student Suicide, 141, 55-69. 
Kagan, V. E. (1998). Vozmozhnost' vyiti na solnechnyi svet [The possibility to come out to the sunlight]. Psikhologicheskaya Gazeta, 9(36), 31-32.

Kann, L., O’Malley Olsen, E., McManus, T., Kinchen, S., Chyen, D., Harris, W. A., \& Wechsler, H. (2011). Sexual identity, sex of sexual contacts, and health-risk behaviors among students in grades 9-12 - Youth Risk Behavior Surveillance, Selected Sites, United States, 2001-2009. Surveillance Summaries, 60(SS07), 1-133.

Klimova, E. A. (2014). Deti-404. LGBT-podrostki: v stenakh molchaniya [Children 404. LGBT-adolescents: in the walls of silence]. Nizhny Tagil.

Kon, I. S. (1998). Lunnyi svet na zare. Liki i maski odnopoloi lyubvi [Moonlight at dawn. Faces and masks of same-sex love]. Moscow: Olimp/AST.

Kon, I. S. (2006). Seks i men'shinstva: Kak gomofobiya stanovitsya ksenofobiei [Sex and minorities: How homophobia becomes xenophobia]. Novoe Vremya, 15, 32-35.

Kosciw, J. G., Palmer, N. A., \& Kull, R. M. (2015). Reflecting resiliency: openness about sexual orientation and/or gender identity and its relationship to well-being and educational outcomes for LGBT students. American Journal of Community Psychology, 55(1-2), 167-178.

Kuper, T. (2014). Litsenziya na travlyu. Gomofobnoe nasilie i presledovanie LGBT-soobshchestva v Rossii [License to bully. Homophobic violence and perpetration of LGBT-community in Russia]. Retrieved from https://www.hrw.org/ru/report/2014/12/15/267949

Lapshina, T. N. (2015, February 10). Psikhologicheskaya rabota s podrostkom s otlichayushcheisya ot traditsionnoi seksual'noi orientatsiei [Psychological counseling of adolescent with unorthodox sexual orientation]. Psikhologicheskaya gazeta. Retrieved from http://www.psy.su/feed/4481/

Lewis, J., Chwee-Lye, C., Logan, M. A., \& Vosvick, M. (2011). Predictors of forgiveness of Self in LGBT adults: Coming out, guilt, and loneliness. Paper presented at the APHA 139th Annual Meeting and Exposition, Washington, DC. Retrieved from https://apha.confex.com/apha/139am/webprogram/Paper243890.html

Lukovitskaya, E. G. (2003). Vospriyatie gomoseksual'nosti [Perception of homosexuality]. In I. N. Kletsina (Ed.), Praktikum po gendernoi psikhologii [Practical course in gender psychology] (pp. 415-426). Saint Petersburg: Piter.

Magee, J. C., Bigelow, L., Dehaan, S., \& Mustanski, B. S. (2012). Sexual health information seeking online: a mixed-methods study among lesbian, gay, bisexual, and transgender young people. Health Education and Behavior, 39(3), 276-289.

Nagornaya, N. P. (2009). "Stress men'shinstva” [Minority stress]. In L. Geidar \& M. Andrushchenko (Eds.), Sotsial'naya rabota s lyud'mi, praktikuyushchimi odnopolye seksual'nye otnosheniya: Teoriya. Metodiki. Luchshie praktiki [Social work with people practicing same-sex relationships: Theory. Techniques. Best practices] (pp. 24-26). Kiev: International HIV/AIDS Alliance in Ukraine.

Ostapenko, I. A. (2004). Gendernaya identichnost'i samoprezentatsiya v Internet-kommunikatsii: Sotsial'nofilosofskii analiz [Gender identity and self-presentation in Internet-communication: Social and philosophical analysis] (PhD dissertation, Rostov State University, Rostov-on-Don, Russian Federation).

Pavlova, T. S., \& Bannikov, G. S. (2013). Modern theories of suicidal behavior in adolescents and young people. Psikhologicheskaya Nauka i Obrazovanie psyedu.ru, 4. Retrieved from http://psyjournals.ru/en/psyedu_ej/2013/n4/65877.shtml

Petrova, E. V. (2015). Theoretical study of the causes of parent's attitudes to adult LGB children. Uchyonye Zapiski: Electronic Scientific Journal of the Kursk State University, 1(33). Retrieved from http://cyberleninka.ru/article/n/teoreticheskoe-issledovanie-faktorov-otnosheniya-roditeley-kvzroslym-detyam-s-gomo-biseksualnoy-identichnostyu 
Pingel, E. S., Thomas, L., Harmell, Ch., \& Bauermeister, J. (2013). Creating comprehensive, youth centered, culturally appropriate sex education: What do young gay, bisexual and questioning men want? Sex Res Social Policy, 10(4). Retrieved from http://www.ncbi.nlm.nih.gov/pmc/articles/ PMC3862289/

Plotko, M. (2013, March 12). Strakh drugogo. Problema gomofobii v Rossii [A fear of Other. Problem of homophobia in Russia]. Demoskop Weekly. Retrieved from http://demoscope.ru/weekly/2013/ 0549/opros07.php

Rothman, E. F., Sullivan, M., Keyes, S., \& Boehmer, U. (2012). Parents' supportive reactions to sexual orientation disclosure associated with better health: Results from a population-based survey of LGB adults in Massachusetts. Journal of Homosexuality, 59(2), 186-200.

Russell, S. T., \& Joyner, K. (2001). Adolescent sexual orientation and suicide risk: Evidence from a national study. American Journal of Public Health, 91(8), 1276-1281.

Ryana, W. S., Legateb, N., \& Weinstein, N. (2015). Coming out as lesbian, gay, or bisexual: The lasting impact of initial disclosure experiences. Self and Identity, 14(5), 549-569.

Sabunaeva, M. L. (2009). Osnovy okazaniya psikhologicheskoi pomoshchi gomoseksualam [Principles of rendering of psychological help to homosexuals]. In L. Geidar \& M. Andrushchenko (Eds.), Sotsial'naya rabota s lyud'mi, praktikuyushchimi odnopolye seksual'nye otnosheniya: Teoriya. Metodiki. Luchshie praktiki [Social work with people who practice same-sex relationships: Theory. Techniques. Best practices] (pp. 30-36). Kiev: International HIV/AIDS Alliance in Ukraine.

Soboleva I., \& Bakhmetjev Y. (2014). "I was basically kicked off": Reaction of LGBT on the "Prohibition of homosexuality propaganda". The Journal of Social Policy Studies, 12(2), 217-232.

Strokova, S. S. (2013). Change of the model of homosexuality in psychodynamic approach (review of foreign literature references). Sovremennaya Zarubezhnaya Psikhologiya, 2(3), 81-92. Retrieved from http://psyjournals.ru/jmfp/2013/n3/63508.shtml

Ybarra, M. L., Mitchell, K. J., Palmer, N. A., \& Reisner, S. L. (2015). Online social support as a buffer against online and offline peer and sexual victimization among U.S. LGBT and non-LGBT youth. Child Abuse and Neglect, 39, 123-136.

Zinovieva, E. V. (2007). Osobennosti Ya-kontseptsii zhenshchin netraditsionnoi seksual'noi orientatsii [Characteristics of self-concept of women with unorthodox sexual orientation] (Extended abstract of PhD dissertation, Saint Petersburg University, Saint Petersburg, Russian Federation).

Tatiana N. Lapshina - associate professor in general and developmental psychology, Social Management Academy of Moscow Region, Ph.D.

Research area: affective psychophysiology, psychology of emotions, emotional intelligence, psychology of education, psychology in school, psychological counseling, existential psychotherapy, gestalt-therapy, psychology of corporeality.

E-mail: tatyana.lapshina@gmail.com

Anna S. Kochetkova - volunteer, head of psychological help area in group "Deti-404”.

Research area: psychology of abilities and giftedness, differential psychophysiology, gender psychology, psychology of trauma, memory psychology.

E-mail: hana.kochetkovavaneyan@gmail 